\title{
The effects of genotype and overfeeding on fat level and composition of adipose and muscle tissues in ducks
}

\author{
Pascal CHARTRIN ${ }^{\mathrm{a} *}$, Marie-Dominique BERNADET ${ }^{\mathrm{b}}$, Gérard GUY ${ }^{\mathrm{b}}$, \\ Jacques MOUROT ${ }^{\mathrm{c}}$, Michel J. DUCLOS ${ }^{\mathrm{a}}$, Elisabeth BAÉZA ${ }^{\mathrm{a}}$ \\ ${ }^{a}$ Station de Recherches Avicoles, INRA Tours, 37380 Nouzilly, France \\ ${ }^{\mathrm{b}}$ Unité Expérimentale des Palmipèdes à Foie Gras, INRA Artiguères, 40280 Benquet, France \\ c Unité Systèmes d'Élevage, Nutrition et Alimentation Humaine, INRA, 35590 St Gilles, France
}

(Received 6 January 2005 - Accepted 2 February 2006)

\begin{abstract}
This study was conducted to evaluate the effects of genotype (Muscovy, Pekin and their crossbred hinny and mule ducks) and overfeeding (14 days from 12 weeks of age) on the quantity and quality of lipid deposition in adipose and muscle tissue in ducks. Samples of muscles (Pectoralis major and Iliotibialis superficialis) and abdominal fat were collected at 14 weeks of age to determine lipid levels, lipid classes and fatty acid composition. By comparison with the other genotypes, Pekin ducks exhibited higher amounts of abdominal fat and higher lipid levels in muscles (+105 and $+120 \%$ in P. major and Iliotibialis superficialis, respectively) by comparison with Muscovy ducks. By comparison with other genotypes, Muscovy ducks exhibited the lowest triglyceride and phospholipid levels in muscles and Pekin ducks the highest levels. Muscovy ducks also showed the lowest cholesterol levels in I. Superficialis muscles. Muscovy ducks exhibited the highest levels of saturated fatty acids (SFA) and poly-unsaturated fatty acids (PUFA) in muscle and adipose tissues and the lowest levels of mono-unsaturated fatty acids (MUFA), and Pekin ducks exhibited the reverse. For all these parameters, the crossbred ducks always presented intermediate values. Overfeeding induced an accumulation of lipids in adipose and muscle tissues (1.2- to 1.7fold, depending on muscle type and genotype). This increase was higher in P. major than in $I$. superficialis muscles. The increase in the amount of abdominal fat was 1.7- to 3.1-fold, depending on genotype. This increase in lipid levels in peripheral tissues was mainly induced by triglyceride deposition. Finally, it induced a considerable increase in proportions of MUFA (particularly oleic acid) (expressed as \% of total fatty acids) at the expense of PUFA (particularly arachidonic acid) and SFA. However, the amounts (expressed as g per $100 \mathrm{~g}$ of tissue) of SFA and MUFA increased in tissues while the amounts of PUFA remained unchanged in muscles and decreased in abdominal fat. The quantity and quality of fat deposition in peripheral tissues depends on the liver's ability to synthesise and also to export lipids.
\end{abstract}

lipids / fatty acids / meat / muscles / ducks

\footnotetext{
*Corresponding author: chartrin@tours.inra.fr
} 
Résumé - Influence du génotype et du gavage sur la teneur en lipides des tissus adipeux et musculaires de canards. Cette étude avait pour objectif d'évaluer les effets du génotype (Barbarie, Pékin et leurs croisements, hinny et mulard) et du gavage (14 jours à partir de l'âge de 12 semaines) sur la quantité et la qualité des lipides déposés dans le tissu adipeux et les muscles de canards. Des échantillons de muscle (Pectoralis major et Iliotibialis superficialis) et de gras abdominal ont été collectés à l'âge de 14 semaines afin de déterminer leur teneur en lipides, les classes de lipides et la composition en acides gras. Par comparaison avec les autres génotypes, les canards Pékin avaient plus de gras abdominal et une quantité de lipides intramusculaires plus élevée $(+105$ et $+120 \%$ dans le P. major et l'Iliotibialis superficialis, respectivement par comparaison avec le canard de Barbarie). Par comparaison avec les autres génotypes, les canards de Barbarie présentaient les teneurs en triglycérides et phospholipides dans les muscles les plus faibles et les canards Pékin les plus élevées. La teneur en cholestérol de l'Iliotibialis superficialis était également plus faible chez les canards de Barbarie. Dans les muscles et les tissus adipeux, les canards de Barbarie présentaient les proportions d'acides gras saturés (AGS) et poly-insaturés (AGPI) les plus élevées et le pourcentage d'acides gras mono-insaturés (AGMI) le plus faible. La situation inverse était observée chez les canards Pékin. Pour tous ces paramètres, les canards hinnies et mulards présentaient des valeurs intermédiaires. Le gavage a induit une accumulation de lipides dans les tissus adipeux et musculaires : multiplié par 1,2 à 1,7 selon le muscle et le génotype. Cette augmentation était plus importante dans le P. major que dans l'Iliotibialis superficialis. La quantité de gras abdominal a été multipliée par 1,7 à 3,1 selon le génotype. Cette augmentation de la teneur en lipides des tissus périphériques a surtout été induite par un dépôt de triglycérides. Enfin, le gavage accroît le pourcentage (exprimé en \% des AG totaux) d'AGMI (en particulier l'acide oléique) au détriment des AGPI (en particulier l'acide arachidonique) et des AGS. Cependant, les quantités (exprimées en g par $100 \mathrm{~g}$ de tissu) d'AGS et d'AGMI augmentent dans les tissus alors que celle des AGPI reste stable dans les muscles et décroît dans le gras abdominal. La quantité et la qualité des lipides déposés dans les tissus périphériques dépendent donc de l'aptitude du foie à les synthétiser mais également à les exporter.

lipides / acides gras / viande / muscles / canards

\section{INTRODUCTION}

Intramuscular fat (IMF) is involved in determining meat quality, particularly the nutritional and sensory characteristics and storage ability [16]. Lipid levels in duck meat are higher than in chicken and turkey meat and depend on the species, age, sex and nutrition [3]. Moreover, in Pekin and Muscovy ducks, selection for low abdominal fat also decreases lipid levels in muscles $[4,22]$, but this type of selection has no effect on IMF in broiler chickens [24]. By comparison with lean Muscovy ducks, lipid levels of breast meat were found to be twice as high in overfed Muscovy ducks [28]. Depending on the source of energy in the diet (starch and lipids) the fatty acid profile of IMF in poultry reflects a balance between hepatic lipogenesis and dietary lipids [21]. In birds, lipids are mainly synthesised in the liver and then exported to peripheral tissues, including the muscles [18]. Guy et al. [13] and Hermier et al. [14] showed that different duck genotypes (Pekin, Muscovy and their crossbred hinny and mule ducks) present different susceptibilities to storing lipids in the liver and in peripheral tissues such as adipose tissues and muscles during an overfeeding period. Pekin ducks show more marked extra-hepatic fattening (higher amounts of abdominal and subcutaneous fat) and Muscovy ducks exhibit the opposite. It therefore seemed interesting to use these different duck genotypes in combination with feeding levels (ad libitum vs. overfeeding) to analyse more precisely the consequences of hepatic export ability on lipid quantity and quality (lipid classes and fatty acid profiles) deposited in muscles and abdominal fat. 


\section{MATERIALS AND METHODS}

\subsection{Animals and diets}

We used male ducks from four different genotypes: Pekin, Muscovy and their crossbred mule (male Muscovy duck $\times$ female Pekin duck) and hinny ducks (male Pekin duck $\times$ female Muscovy duck). The ducks (50 per genotype) originated from the same sires and dams provided by the Grimaud Company (Roussay, France). They were reared under natural light and temperature conditions at the Experimental Station for Waterfowl Breeding (INRA Artiguères, France), distributed at one genotype per pen. They were fed ad libitum from hatching to 6 weeks of age. From 6 to 12 weeks of age, the birds were fed on a restricted diet at levels appropriate to the ingestion ability of each genotype (200$250 \mathrm{~g}$ per duck at the beginning, increasing to $360-380 \mathrm{~g}$ at the end of the period). At 12 weeks of age, 35 ducks per genotype were overfed at the maximum of their ingestion potential for 14 days with corn and corn meal (Tab. I). During the overfeeding period, 12 ducks per genotype were fed with the growing diet ad libitum (controls). The composition and main characteristics of the diets (starting, growing and overfeeding) are shown in Tables I and II. The overfeeding diet had lower protein levels, higher lipid levels and higher levels of metabolisable energy than the growing diet. The differences in fatty acid composition were small.

\subsection{Growth and overfeeding performance}

Growth rate and feed conversion ratio were evaluated by the individual weighing of animals and measuring food consumption per genotype $(\mathrm{n}=1)$ at 4,6 and 12 weeks of age. At 14 weeks of age, 8 ducks per genotype and dietary treatment chosen at random were weighed and sacrificed by sectioning of the neck. Immediately after bleeding, Pectoralis major (a breast muscle), Iliotibialis superficialis (a thigh muscle), liver and abdominal fat were excised and weighed. The samples of adipose and muscle tissues were frozen and stored at $-20{ }^{\circ} \mathrm{C}$.

The present study was carried out in agreement with the French legislation on animal experimentation and with authorisation from the French Ministry of Agriculture (Animal Health and Protection Directorate).

\subsection{Chemical analysis}

Moisture and mineral levels in the diets were determined with the oven method [2], and protein levels with the Kjeldahl copper catalyst method [2]. Total lipids were extracted quantitatively from diets and tissues, by homogenising samples of minced tissue in chloroform/methanol $2 / 1 \mathrm{v} / \mathrm{v}$ and collecting gravimetrically [9]. The classes of lipids were determined using Iatroscan (Iatron, Tokyo, Japan) with 10 silica-gel thin layer chromatography rods and a flame ionisation detector system (TLC-FID) according to Mares et al. [19]. The hydrogen flow rate was $160 \mathrm{~mL}$ per min, the air flow rate $2 \mathrm{~L}$ per min and scanning speed $0.3 \mathrm{~cm}$ per s. The software used (Boreal, JMBS Development, Grenoble, France) recorded chromatograms and integrated peaks with reference to an external standard (Sigma, St Quentin Fallavier, France). The fatty acid composition was determined after transmethylation of lipids [20] by gas chromatography (Perkin Elmer Autosystem, St Quentin en Yvelines, France). Injector and detector (FID) temperatures were $250{ }^{\circ} \mathrm{C}$, the carrier gas was nitrogen with a head column pressure of 16.5 psi using a capillary column $(25 \mathrm{~m} \times 0.22 \mathrm{~mm}$, BPX70, SGE, Villeneuve St Georges, France). 
Table I. Composition and characteristics of feed for rearing and overfeeding periods. The preparation for overfeeding contained corn (25\%), corn meal (35\%) and water (40\%).

\begin{tabular}{|c|c|c|c|}
\hline Composition (g per kg) & $\begin{array}{c}\text { Starting } \\
(0-4 \text { weeks })\end{array}$ & $\begin{array}{c}\text { Growing } \\
(4-12 \text { weeks })\end{array}$ & $\begin{array}{c}\text { Overfeeding } \\
(12-14 \text { weeks) }\end{array}$ \\
\hline Wheat & 200.00 & 254.50 & \\
\hline Wheat starch & & & 2.90 \\
\hline Corn & 357.02 & 370.48 & 988.49 \\
\hline Sorghum & & 80.00 & \\
\hline Triticale & 100.00 & & \\
\hline Extruded soybean seeds & 40.00 & 15.00 & \\
\hline Rapeseed oilmeal solvent extracted & 30.00 & 50.00 & \\
\hline Soybean meal & 184.75 & 138.75 & \\
\hline Sunflower meal & 29.00 & 44.50 & \\
\hline Sugarcane molasses & 20.00 & 15.00 & \\
\hline Calcium carbonate & 13.50 & 10.00 & \\
\hline Dicalcium phosphate & 17.75 & 15.00 & \\
\hline Sodium chloride & 1.00 & 1.75 & 1.45 \\
\hline Sodium bicarbonate & 2.50 & 1.50 & 1.45 \\
\hline DL-methionine & 1.88 & 1.12 & \\
\hline Choline- $\mathrm{HCl} 75 \%$ & 0.60 & 0.40 & \\
\hline Vitamin and mineral supplement & $2.00^{1}$ & $2.00^{1}$ & $5.71^{2}$ \\
\hline \multicolumn{4}{|l|}{ Characteristics $(\mathrm{g}$ per $\mathrm{kg}) *$} \\
\hline Metabolisable Energy (MJ per kg) & 11.83 & 11.68 & 13.92 \\
\hline Crude proteins & 175.10 & 160.00 & 82.46 \\
\hline Total lipids & 30.40 & 27.40 & 37.36 \\
\hline Lysine & 9.20 & 7.80 & - \\
\hline Sulphur amino acids & 7.70 & 7.10 & - \\
\hline Calcium & 11.0 & 9.00 & - \\
\hline Available phosphorus & 4.50 & 4.00 & - \\
\hline
\end{tabular}

* Calculated values.

${ }^{1}$ Supplied per kilogram of diet: 9000 IU vitamin A; 1500 IU cholecalciferol; $22 \mathrm{mg}$ vitamin E; $2 \mathrm{mg}$ vitamin $\mathrm{K}_{3} ; 1 \mathrm{mg}$ vitamin $\mathrm{B}_{1} ; 85 \mathrm{mg} \mathrm{Mn} ; 80 \mathrm{mg} \mathrm{Zn} ; 30 \mathrm{mg} \mathrm{Fe} ; 15 \mathrm{mg} \mathrm{Cu}$.

${ }^{2}$ Supplied per kilogram of diet: $3.48 \mathrm{mg}$ vitamin E; $34.22 \mathrm{mg} \mathrm{Mn} ; 29.58 \mathrm{mg} \mathrm{Zn;} 17.40 \mathrm{mg} \mathrm{Fe}$; $4.64 \mathrm{mg} \mathrm{Cu} ; 1.16 \mathrm{mg} \mathrm{I}$.

Methyl esters were identified and quantified by comparison with standards (Sigma, St Quentin Fallavier, France).

\subsection{Statistical analysis}

Data were analysed by analysis of variance using the SAS General Linear Model procedure [27]. The model included the main effects of genotype, feeding plan and their interaction. Significant differ- ences between means were shown in the different groups according to the NewmanKeul test.

\section{RESULTS}

\subsection{Feed consumption, growth performance and body composition of ducks}

Muscovy ducks displayed the lowest feed conversion ratios and consumption 
Table II. Chemical composition of feed for rearing and overfeeding periods. The preparation for overfeeding contained corn (25\%), corn meal (35\%) and water (40\%).

\begin{tabular}{|c|c|c|c|}
\hline Composition (\%) & $\begin{array}{c}\text { Starting } \\
(0-4 \text { weeks })\end{array}$ & $\begin{array}{c}\text { Growing } \\
\text { (4-12 weeks) }\end{array}$ & $\begin{array}{c}\text { Overfeeding } \\
\text { (12-14 weeks) }\end{array}$ \\
\hline Dry matter & 89.86 & 89.21 & 89.25 \\
\hline Crude protein & 18.21 & 15.98 & 8.28 \\
\hline Minerals & 5.92 & 5.03 & 1.57 \\
\hline Total lipids & 3.34 & 2.84 & 3.38 \\
\hline Triglycerides* & 76.68 & 77.18 & 89.01 \\
\hline Cholesterol* & 5.72 & 4.97 & 3.37 \\
\hline Phospholipids* & 17.60 & 17.83 & 7.62 \\
\hline$\Sigma \mathrm{SFA}^{* *}$ & 17.17 & 16.10 & 14.52 \\
\hline C16:0 & 12.31 & 12.55 & 11.56 \\
\hline C18:0 & 3.06 & 2.37 & 2.03 \\
\hline C20:0 & 1.03 & 1.18 & 0.94 \\
\hline C22:0 & 0.77 & nd & nd \\
\hline$\Sigma$ MUFA $^{* *}$ & 24.98 & 28.36 & 27.43 \\
\hline C18:1 n-9 & 24.98 & 28.36 & 27.43 \\
\hline$\sum$ PUFA $^{* *}$ & 57.85 & 55.54 & 58.03 \\
\hline C18:2 n-6 & 54.24 & 53.32 & 56.80 \\
\hline C18:3 n-3 & 3.61 & 2.22 & 1.23 \\
\hline PUFA+MUFA/SFA & 4.82 & 5.21 & 5.89 \\
\hline
\end{tabular}

SFA, MUFA, PUFA = Saturated, Mono-Unsaturated and Poly-Unsatured Fatty Acids.

$*=$ Expressed as $\%$ of total lipids. $* *=$ Expressed as $\%$ of total fatty acids

nd $=$ not detected.

Table III. The effects of duck genotype on feed conversion ratio (FCR, $\mathrm{kg}$ of feed/ $\mathrm{kg}$ of weight gain) during the rearing period (0 to 12 weeks), total feed consumption of equivalent dry maize (g) during the overfeeding period (12 to 14 weeks), total feed consumption ( $\mathrm{g}$ ) of control ducks during the same period $(\mathrm{n}=1)$ and body weight $(\mathrm{BW}, \mathrm{g})$ during the rearing period (mean $\pm \mathrm{SEM}, \mathrm{n}=50$ ).

\begin{tabular}{lcccc}
\hline Periods & Muscovy & Hinny & Mule & Pekin \\
\hline FCR during the rearing period & 2.76 & 3.23 & 3.29 & 3.63 \\
Total consumption of overfeeding diet & 8219 & 10341 & 10552 & 9674 \\
Total consumption of growing diet & 3112 & 4027 & 4295 & 3923 \\
BW at 4 weeks & $1257 \pm 92 \mathrm{~d}$ & $1593 \pm 85 \mathrm{c}$ & $1684 \pm 115 \mathrm{~b}$ & $1741 \pm 124 \mathrm{a}$ \\
BW at 6 weeks & $2715 \pm 148 \mathrm{c}$ & $2626 \pm 148 \mathrm{~d}$ & $2846 \pm 209 \mathrm{~b}$ & $2985 \pm 183 \mathrm{a}$ \\
BW at 12 weeks & $4919 \pm 323 \mathrm{a}$ & $4588 \pm 395 \mathrm{~b}$ & $4622 \pm 314 \mathrm{~b}$ & $4477 \pm 294 \mathrm{~b}$ \\
\hline
\end{tabular}

a-d: Significant difference between genotypes for one parameter, $P<0.05$.

of maize or growing diet during the rearing and overfeeding periods, respectively (Tab. III). Pekin ducks had the highest feed conversion ratios during the rearing period. Mule ducks displayed the highest ingestion capacity during the overfeeding period.
By comparison with the other genotypes, Muscovy ducks exhibited the lowest body weights at 4 weeks of age, and the highest at 12 and 14 weeks of age (Tabs. III, IV). Between 4 and 14 weeks of age, body weights of control Muscovy 


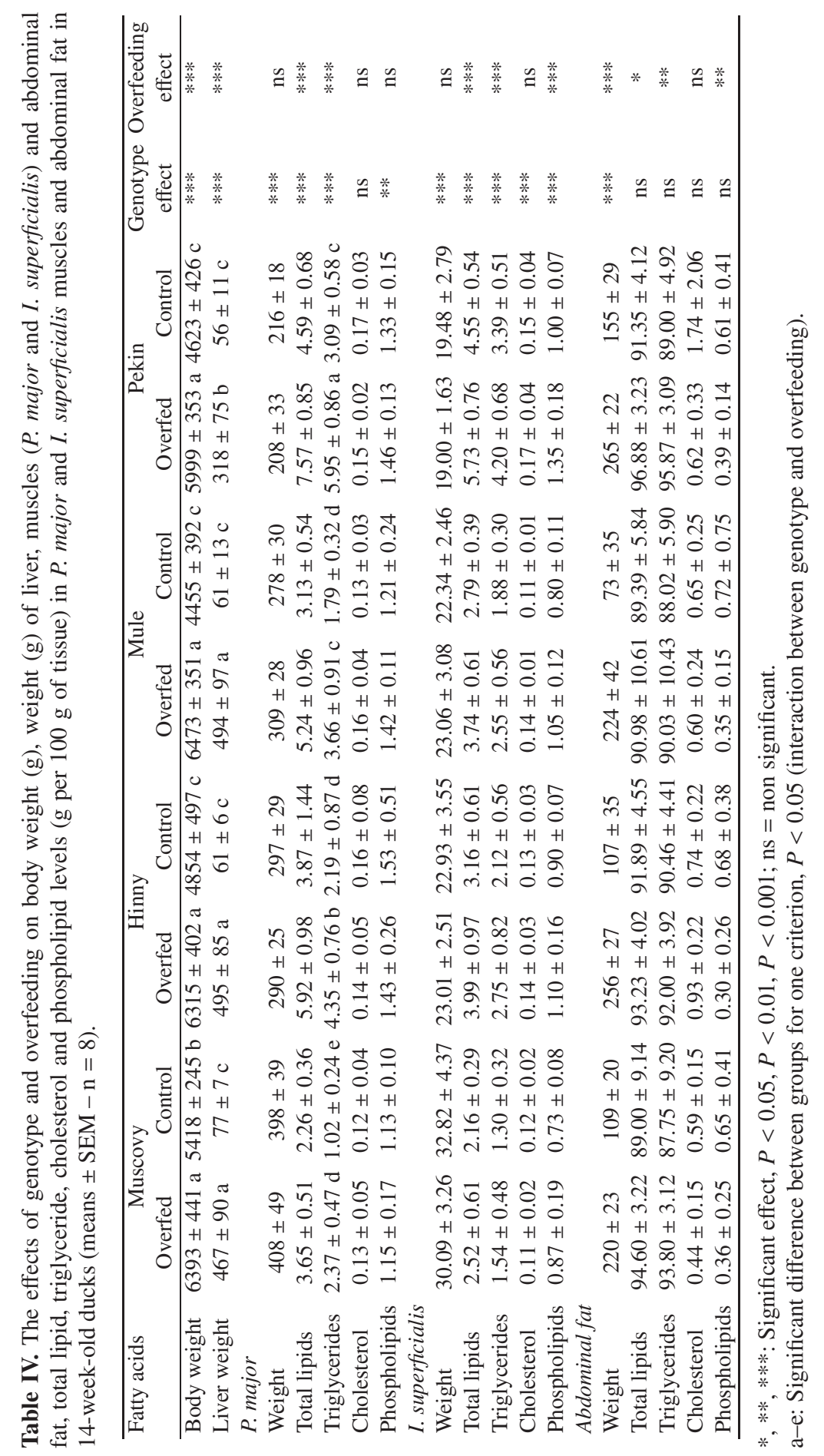


ducks were 4.3 times higher whereas they were 2.6 to 3.0 times higher for the other genotypes.

By comparison with other genotypes, Pekin ducks had the lowest liver weights. Muscovy ducks had the highest muscle weights (Tab. IV).

By comparison with control ducks, overfeeding induced a significant increase in body $(+30 \%)$, liver (7-fold) and abdominal fat (2.2-fold) weights but had no effect on muscle weight (Tab. IV). The increase in body weight was about $45 \%$ for mule ducks, 30\% for hinny and Pekin ducks and $18 \%$ for Muscovy ducks. Liver weight was 8.1 times higher for mule and hinny ducks, 6.1 times higher for Muscovy ducks and 5.7 times higher for Pekin ducks.

\subsection{Lipid levels and composition in muscle and adipose tissues}

By comparison with other genotypes, Muscovy ducks exhibited the lowest lipid, triglyceride and phospholipid levels in muscles and Pekin ducks the highest levels of lipids and triglycerides (Tab. IV). Pekin ducks had the highest cholesterol levels in I. superficialis muscle. In $P$. major muscle, the cholesterol levels were similar for all genotypes. Triglyceride and phospholipid levels were lower in I. superficialis than in $P$. major muscles (calculated average of 2.47 vs. 3.05 and 0.98 vs. $1.33 \mathrm{~g}$ per $100 \mathrm{~g}$ of muscle) and cholesterol levels were similar (calculated average of $0.14 \mathrm{~g}$ per $100 \mathrm{~g}$ of muscle). Genotype had no significant effect on lipid levels or lipid classes in abdominal fat (Tab. IV). Abdominal fat had 30 times more triglycerides than breast muscle (calculated average of $91 \mathrm{vs.} 3 \mathrm{~g}$ per $100 \mathrm{~g}$ of tissue) and 6 times more cholesterol (calculated average of 0.79 vs. $0.14 \mathrm{~g}$ per $100 \mathrm{~g}$ of tissue). By contrast, phospholipid levels were lower (calculated average of 0.51 vs. $1.33 \mathrm{~g}$ per $100 \mathrm{~g}$ of tissue).
Overfeeding induced a significant increase in lipid levels of $P$. major (1.6-fold) and I. superficialis muscles (1.3-fold) and a slight increase in the amount of abdominal fat $(+4 \%$, Tab. IV). Triglyceride levels only increased in the $P$. major muscle (2.0-fold, Tab. IV). Triglyceride and phospholipid levels were higher in overfed ducks than in control ducks in I. superficialis muscle $(+27 \%$ for both lipid classes, Tab. IV). Overfeeding induced a significant increase in triglyceride levels $(+4.6 \%)$ to the detriment of phospholipid levels in abdominal fat (Tab. IV).

The main fatty acids in muscle and adipose tissues were $\mathrm{C} 16: 0$ (23-25\%) and C18:0 (7-10\%) (saturated fatty acids, SFA), C18:1 n-9 (40-52\%) and C16:1 n7 (3-4\%) (mono-unsaturated fatty acids, MUFA), C18:2 n-6 (12-13\%) and C20:4 n-6 (4-5\%) (poly-unsaturated fatty acids, PUFA, Tabs. V-VII). This latter was not detected in abdominal fat (Tab. VII). Muscles and fatty tissues contained high proportions of n- 6 fatty acids and very low proportions of n-3 fatty acids. I. superficialis muscle had higher proportions of MUFA and lower proportions of SFA and PUFA than the P. major muscle (Tab. VI). Abdominal fat had higher proportions of MUFA and lower proportions of PUFA than muscle tissues. Overall Pekin ducks exhibited the highest proportions of MUFA and the lowest proportions of SFA and PUFA in all tissues analysed (Tabs. VVII). Muscovy ducks exhibited the highest proportions of SFA and PUFA and the lowest proportions of MUFA.

In all tissues, overfeeding induced an increase in the proportions of MUFA and a decrease in the proportions of PUFA (Tabs. V-VII). The increase in the proportions of SFA was only significant in I. superficialis muscle and abdominal fat. Calculating the amounts of fatty acids per $100 \mathrm{~g}$ of tissue showed that overfeeding finally induced large increases in SFA and MUFA levels in all tissues (Fig. 1). 
P. Chartrin et al.

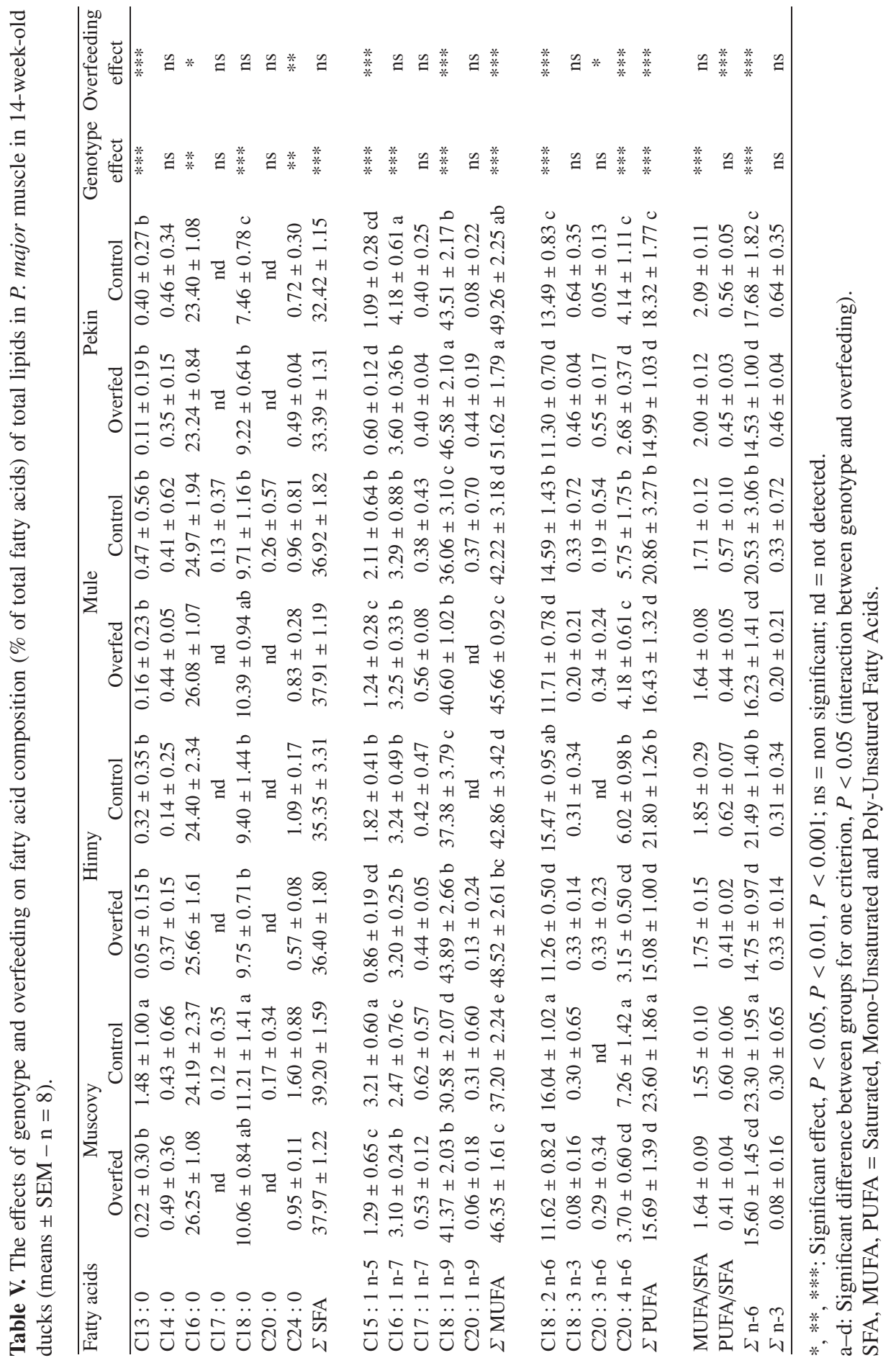


Lipid deposition in duck muscle

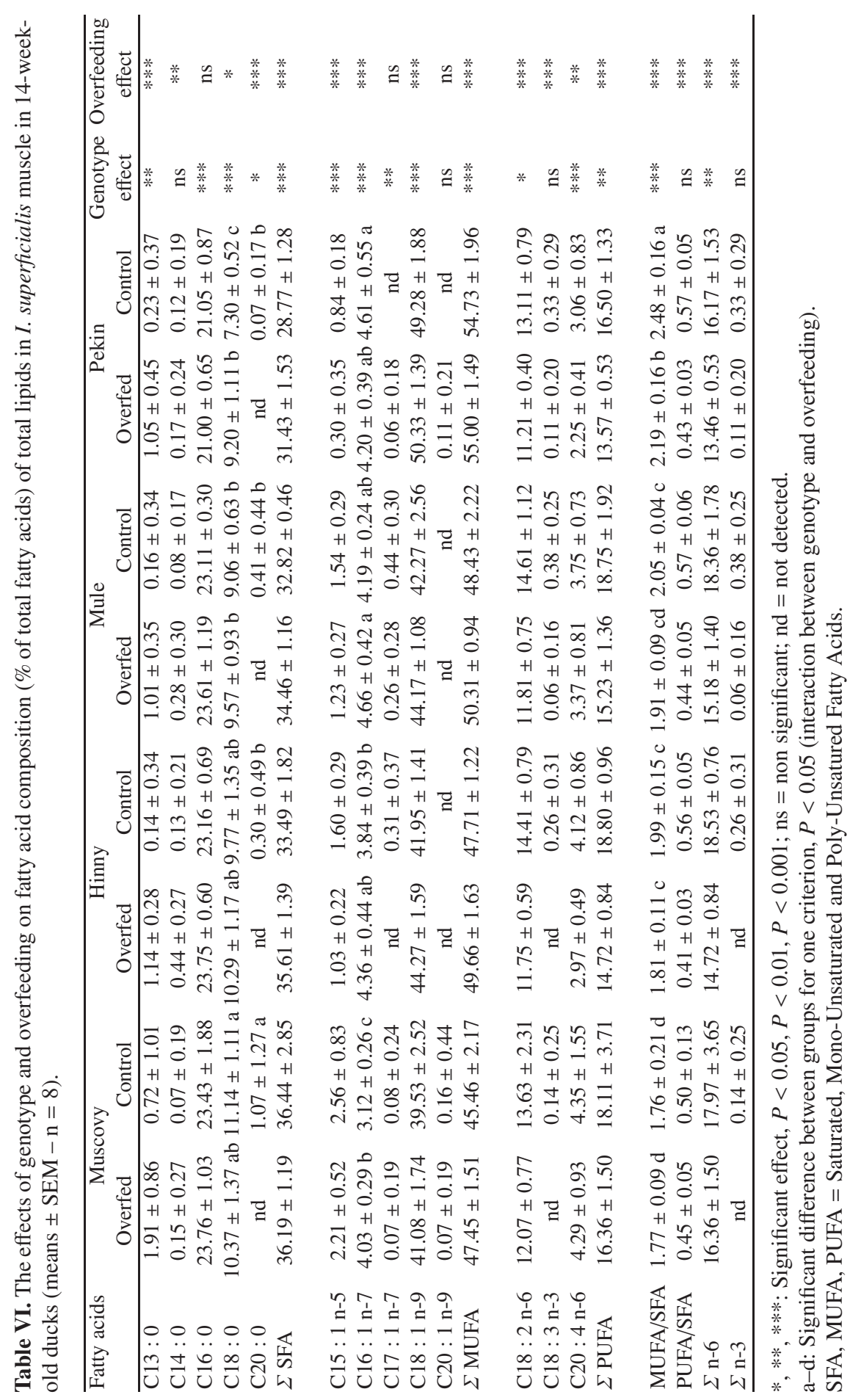


P. Chartrin et al.

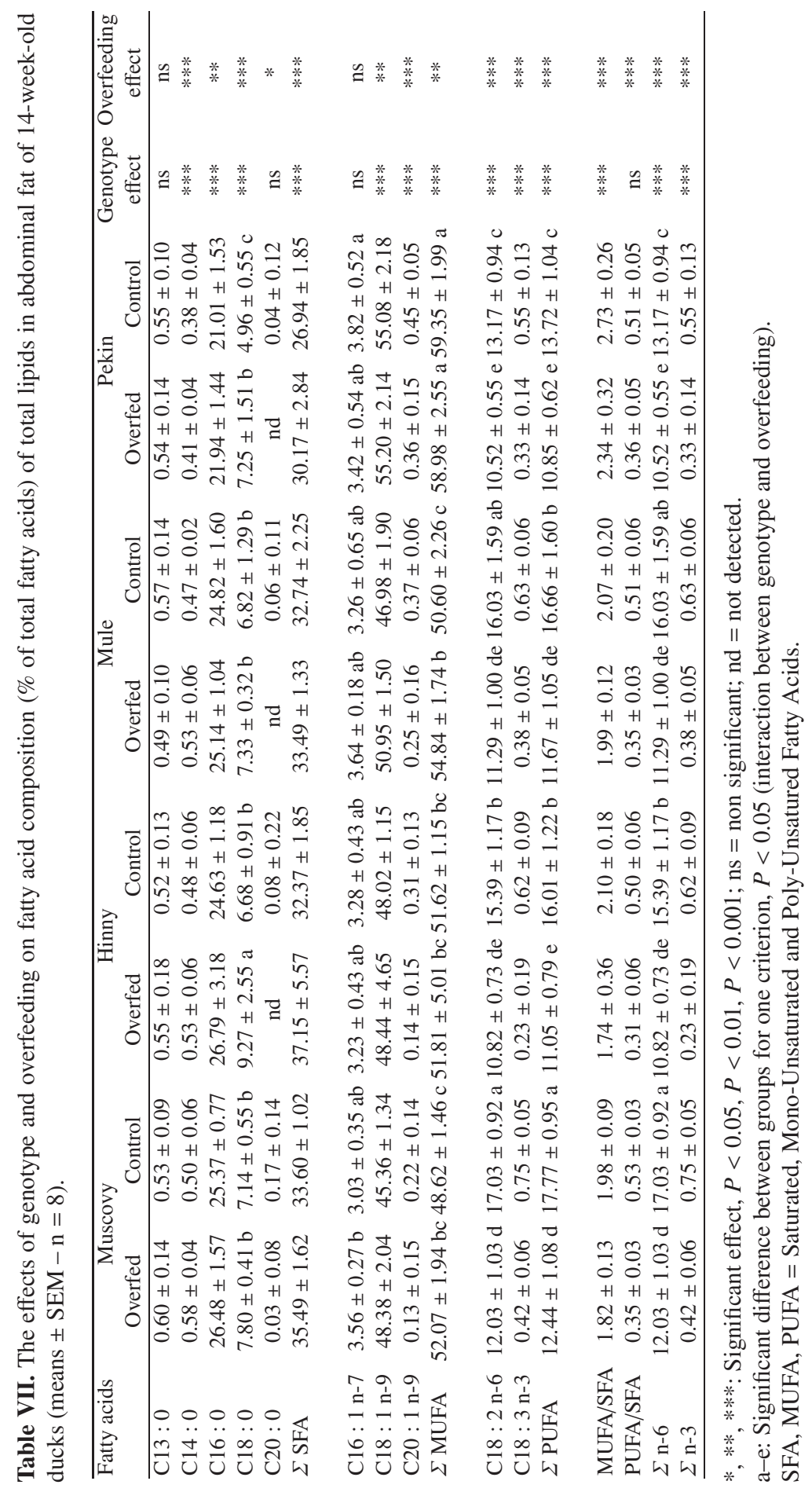



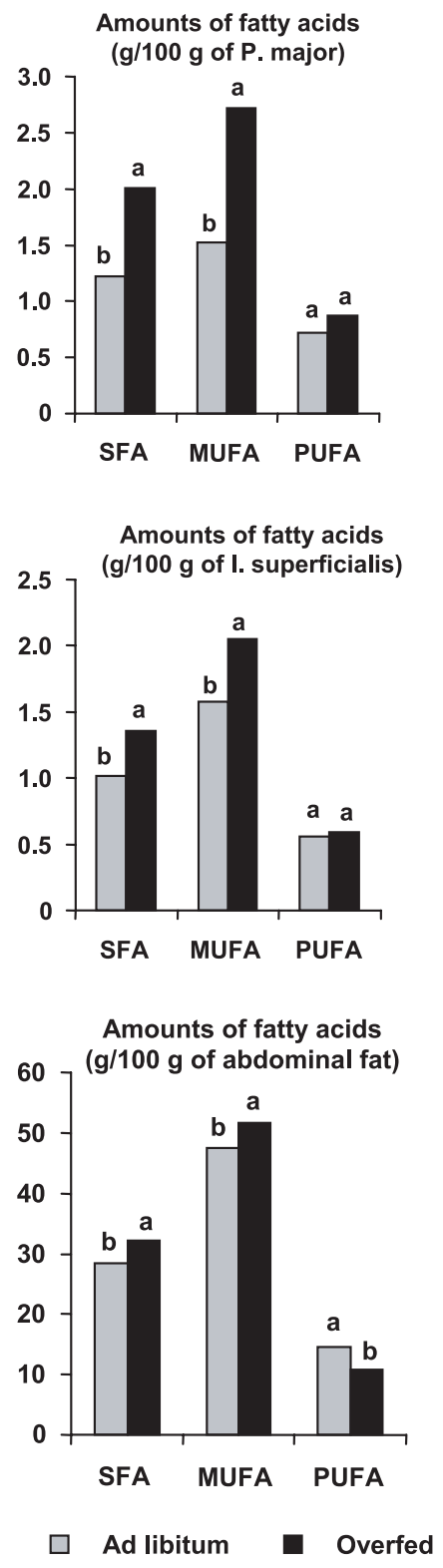

Figure 1. The effects of feeding level on the amounts of saturated, mono-unsaturated and poly-unsaturated fatty acids (SFA, MUFA, PUFA) in P. major and I. superficialis muscles and abdominal fat of 14-week-old ducks $(\mathrm{n}=$ 32).

a, b: Significant difference between overfed and ad libitum fed ducks, $P<0.05$.
PUFA levels remained unchanged in muscle tissues and decreased in abdominal fat (Fig. 1). Overfeeding had greater effects in $P$. major than in I. superficialis muscle and abdominal fat. Finally, we found significant negative correlations between proportions of PUFA and total lipid levels in muscles ( -0.66 and -0.58 for $P$. major and I. superficialis muscles, respectively).

\section{DISCUSSION}

Lean Muscovy ducks exhibited the lowest feed conversion ratios during the rearing and overfeeding periods, and Pekin ducks the highest. Broiler chickens selected for low abdominal fat also had better feed conversion ratios than chickens selected for high abdominal fat [1]. This characteristic could suggest that, as in chickens selected for low abdominal fat, Muscovy ducks fed ad libitum were leaner than Pekin ducks because of lower lipogenesis activity.

During the overfeeding period, mule and hinny ducks ingested the highest amounts of feed and Muscovy ducks the lowest. This observation confirmed the previous results of Guy et al. [12,13]. The ingestion ability of mule and hinny ducks benefits from a heterosis effect and this could partly explain their ability to produce large fatty livers. Indeed, when the amount of feed during the overfeeding period was adjusted to body weight, mule ducks produced smaller fatty livers than Muscovy ducks [8]. In spite of lower feed consumption, Muscovy ducks were able to produce heavy fatty livers. This genotype is therefore efficient in using nutrients for lipid synthesis when overfed.

By comparison with the other genotypes, Muscovy ducks displayed later body and muscle development but higher growth potential, as previously reported by Ricard [25]. At 14 weeks of age, they exhibited the highest body weight, the highest muscle 
weight and the lowest fattiness, and for these reasons this species has been chosen for the production of duck meat in France [25]. By contrast, the Pekin duck is characterised by early body development. Their adipose tissues are therefore probably developed earlier (adipocyte hypertrophy induced by lipid deposition), and when compared at the same age Pekin ducks have higher carcass fattiness and higher IMF than Muscovy ducks. The difference in muscle weight between Muscovy ducks and the other genotypes $(+63 \%$ and $+90 \%$ for I. superficialis and P. major muscles, respectively, by comparison with Pekin ducks) could be partly explained by higher cross-sectional area of muscle fibres (measured by Chartrin et al. [7] on the same birds), and also by a higher number and/or length of muscle fibres.

By comparison with other genotypes, Pekin ducks exhibited smaller fatty livers but greater amounts of abdominal fat and higher lipid levels in muscles $(+105$ and $+120 \%$ in P. major and Iliotibialis superficialis muscles, respectively, by comparison with Muscovy ducks). Guy et al. [13] and Hermier et al. [14] showed that Pekin ducks also display higher levels of subcutaneous adipose tissue than Muscovy ducks. Pekin ducks seem therefore to have greater hepatic ability to export neo-synthesised lipids and this could influence the quality of lipids deposited in peripheral tissues.

We found higher levels of triglycerides and cholesterol in $P$. major muscles of lean Muscovy ducks than Salichon et al. [26], but in our study, the ducks were sacrificed two weeks later. For lean mule ducks, we found equivalent levels to those obtained by Baéza et al. [5]. The quantity of phospholipids was higher in muscles than in abdominal fatty tissue, which contains smaller amounts of cellular membranes. By comparison with other genotypes, Muscovy ducks exhibited the lowest triglyceride and phospholipid levels in muscles and Pekin ducks the highest lev- els. Muscovy ducks also had the lowest cholesterol levels in I. superficialis muscle. Muscovy ducks displaying greater fibre size for a given amount of muscle [7] have a smaller total sarcolemma perimeter and therefore lower structural lipid levels (phospholipids) than the other genotypes.

The diets in the present study contained a high level of carbohydrates (about $600 \mathrm{~g}$ of starch per $\mathrm{kg}$ of overfeeding diet), which favours hepatic lipogenesis [17]. By comparison with other genotypes, Muscovy ducks exhibited the highest proportions of SFA and PUFA and the lowest proportions of MUFA and Pekin ducks displayed the reverse in muscles and adipose tissues. Birds mainly synthesise MUFA such as oleic and palmitoleic acids [15]. Our results suggest that Pekin ducks accumulate more MUFA and SFA in peripheral tissues than the other genotypes, particularly Muscovy ducks (3.08 and 2.00 vs. 1.27 and $1.14 \mathrm{~g}$ per $100 \mathrm{~g}$ of $P$. major).

Overfeeding induced a considerable increase in body weight. This resulted from a dramatic increase in the synthesis of lipids in the liver, accumulated first in the liver and also in peripheral tissues such as adipose tissues and muscles [13, 14]. The lipid levels of muscles increased accordingly (1.2 to 1.7-fold depending on muscle type and genotype). This increase was greater in $P$. major than in I. superficialis muscle which had completed its development before the overfeeding period. The increase in the quantity of abdominal fat was 1.7 to 3.1 times greater depending on the genotype. This increase in lipid levels in peripheral tissues mainly resulted from triglyceride deposition. Finally, overfeeding induced a considerable increase in the amounts of MUFA (particularly oleic acid) and SFA, while the amounts of PUFA remained unchanged in the muscles and decreased in abdominal fat. This result was consistent with those of Girard et al. [11] and Zanusso et al. [28]. Ducks ingest a large quantity of 
carbohydrates (corn) during overfeeding, inducing intense hepatic lipogenesis. The neo-synthesised MUFA are then exported and accumulated in peripheral tissues. The effects of overfeeding on fatty acid composition of muscles are also consistent with the defective incorporation of linoleic acid and linoleic- and linolenic-derived PUFA observed, despite the high proportion of these essential fatty acids in an overfeeding diet based on corn [6]. These authors concluded that de novo hepatic lipogenesis prevails over dietary lipid intake in overfed waterfowl, affecting lipid composition of tissues. Gabarrou et al. [10] also suggested lower $\Delta 5$ and $\Delta 6$ desaturase activity. Finally, we confirmed the negative correlation between proportions of PUFA and total lipid levels in muscles previously reported by Rabot [23] in the chicken.

Overfeeding had no significant effect on the muscle weight. It has already been demonstrated that muscle growth is reduced or stopped during overfeeding [13].

\section{CONCLUSION}

From a dietary point of view, duck meat has a high proportion of unsaturated fatty acids but a low proportion of n-3 fatty acids. Increasing IMF resulted in decreased levels of n-3 and n-6 fatty acids. By combining genotype and overfeeding effects, we were able to obtain a wide range of lipid levels in muscles (from 2.26 to 7.57 in P. major and from 2.16 to 5.73 in I. superficialis). Muscovy ducks displayed the lowest intramuscular lipid, triglyceride and MUFA levels and Pekin ducks the highest. Overfeeding induced a considerable increase in lipid, triglyceride, SFA and MUFA levels in muscles and exacerbated the difference observed between lean Pekin and Muscovy ducks in terms of IMF levels. Except for body weights and the weights of fatty livers, the crossbred hinny and mule ducks always showed values intermediate between those of the parental genotypes for all the criteria measured in this study.

These differences in lipid levels and composition might also influence meat quality (tenderness, juiciness, colour, flavour) and storage ability (lipid oxidation and rancidity) from a sensory point of view and this needs further investigation.

\section{ACKNOWLEDGEMENTS}

We thank the Grimaud Company, and particularly Bernard Retailleau, for producing and providing the animals.

\section{REFERENCES}

[1] Alleman F., Bordas A., Caffin J.P., Daval S., Diot C., Douaire M., Fraslin J.M., Lagarrigue S., Leclercq B., L'engraissement chez le poulet : aspects métaboliques et génétiques, INRA Prod. Anim. 12 (1999) 257264.

[2] AOAC, Official Methods of Analyis, 14th Ed., Arlington, VA, Association of Official Chemists, 1984.

[3] Baéza E., La viande de canard : production et principales caractéristiques, INRA Prod. Anim. 8 (1995) 117-125.

[4] Baéza E., De Carville H., Salichon M.R., Marché G., Leclercq B., Effects of selection, over three and four generations, on meat yield and fatness in Muscovy ducks, Brit. Poultry Sci. 38 (1997) 359-365.

[5] Baéza E., Salichon M.R., Marché G., Wacrenier N., Dominguez B., Culioli J., Effects of age and sex on the structural, chemical and technological characteristics of mule duck meat, Brit. Poultry Sci. 41 (2000) 300-307.

[6] Cazeils J.L., Bouillier-Oudot M., Auvergne A., Candau M., Babilé R., Lipid composition of hepatocyte plasma membranes from geese overfed with corn, Lipids 34 (1999) 937-942.

[7] Chartrin P., Bernadet M.D., Guy G., Mourot J., Duclos M.J., Baéza E., Effect of genotype and overfeeding on lipid deposition in myofibres and intramuscular adipocytes of breast and thigh muscles of ducks, Reprod. Nutr. Dev. 45 (2005) 87-99. 
[8] Davail S., Rideau N., Guy G., André J.M., Hermier D., Hoo-Paris R., Hormonal and metabolic responses to overfeeding in three genotypes of ducks, Comp. Biochem. Phys. A 134 (2003) 707-715.

[9] Folch J., Lees M., Sloane Stanley G.H., A simple method for the isolation and purification of total lipids from animal tissues, J. Biol. Chem. 226 (1957) 497-509.

[10] Gabarrou J.F., Salichon M.R., Guy G., Blum J.C., Hybrid ducks overfed with boiled corn develop an acute hepatic steatosis with decreased choline and polyunsaturated fatty acid level in phospholipids, Reprod. Nutr. Dev. 36 (1996) 473-484.

[11] Girard J.P., Culioli J., Denoyer C., Berdague J.L., Touraille C., Discrimination de deux populations chez deux espèces de volaille sur la base de leur composition en lipides, Arch. Geflügelkd 57 (1993) 9-15.

[12] Guy G., Rousselot-Pailley D., Gourichon D., Comparaison des performances de l'oie, du canard mulard et du canard de Barbarie soumis au gavage, Ann. Zootech. 44 (1995) 297-305.

[13] Guy G., Hermier D., Davail S., Bely M., André J.M., Hoo-Paris R., Meat production and force feeding ability of different types of ducks, in: 1st World Waterfowl Conference, Taichung, Taïwan, 1-4/12/99, 1999, pp. 462-468.

[14] Hermier D., Guy G., Guillaumin S., Davail S., André J.M., Hoo-Paris R., Differential channelling of liver lipids in relation to susceptibility to hepatic steatosis in two species of ducks, Comp. Biochem. Phys. B 135 (2003) 663-675.

[15] Klasing K., Lipids, in: Comparative Avian Nutrition, CAB International, Davis, USA, 1998, pp. 171-200.

[16] Lebret B., Mourot J., Caractéristiques et qualité des tissus adipeux chez le porc. Facteurs de variation non génétiques, INRA Prod. Anim. 11 (1998) 131-143.

[17] Lessire M., Matières grasses alimentaires et composition lipidique des volailles, INRA Prod. Anim. 14 (2001) 365-370.
[18] Leveille G.A., O'Hea E.K., Chkrabarty K., In vivo lipogenesis in the domestic chicken, Proc. Soc. Exp. Biol. Med. 128 (1968) 398401.

[19] Mares P., Ranny M., Sedlacek J., Skorepa J., Chromatography analysis of blood lipids, Comparison between gas chromatography and thin layer chromatography with flame ionisation detector, J. Chromatogr. 277 (1983) 295-305.

[20] Morrisson W.R., Smith M.L., Preparation of fatty acid methyl esters and dimethylacetates from lipid with boron trifluoride methanol, J. Lipid Res. 5 (1964) 600-608.

[21] Mourot J., Hermier D., Lipids in monogastric animal meat, Reprod. Nutr. Dev. 41 (2001) 109-118.

[22] Powell J.C., The domestic duck - A preliminary investigation of eating quality, in: 19th World's Poultry Congress, Amsterdam, The Netherlands, 20-24/09/92, Vol. 3, 1992, pp. 106-108.

[23] Rabot C., L'âge d'abattage, critère essentiel de la charte label, Viandes Prod. Carnés 20 (1999) 97-100.

[24] Ricard F.H., Leclercq B., Touraille C., Selecting broilers for low or high abdominal fat: distribution of carcass fat and quality of meat, Brit. Poultry Sci. 24 (1983) 511-516.

[25] Ricard F.H., Composition anatomique de la carcasse du canard mulard comparé aux deux types parentaux, in: Comptes rendus de la Conférence Avicole WPSA-SIMAVIP, Cahier n³, 1986, pp. 47-64.

[26] Salichon M.R., Baéza E., Leclercq B., Caractéristiques biochimiques des filets de canard de Barbarie, Sci. Aliment. 17 (1997) 227-233.

[27] SAS, SAS/STAT user's guide, SAS Institute Inc., Cary, NC, 1989.

[28] Zanusso J., Rémignon H., Guy G., Manse H., Babilé R., The effects of overfeeding on myofibre characteristics and metabolical traits of the breast muscle in Muscovy ducks (Caïrina moschata), Reprod. Nutr. Dev. 43 (2003) 105-115. 